\title{
Effects of clitoral reconstruction for female genital mutilation on perinatal outcomes: a retrospective case-control study
}

\author{
Sebastien Madzou ${ }^{1}$, Chloe Reau-Guisti ${ }^{1}$, Soazig Herve ${ }^{1}$, Katherine Zhu ${ }^{2}$, Charlemagne \\ Ouédrago $^{3}$, Caroline Verhaeghe ${ }^{1}$, Philippe Gillard ${ }^{1}$, Laurent Catala ${ }^{1}$, Vanessa Combaud ${ }^{1}$, \\ Philippe Descamps ${ }^{4}$, Guillaume Legendre ${ }^{1}$, and Romain Corroenne ${ }^{1}$ \\ ${ }^{1} \mathrm{CHU}$ Angers \\ ${ }^{2}$ Baylor College of Medicine \\ ${ }^{3}$ Bogodo OUagadougou University Hospital \\ ${ }^{4} \mathrm{CHU}$
}

May 21, 2020

\begin{abstract}
Objectives: To investigate the perinatal outcomes of women with a history of female genital mutilation (FGM) who underwent clitoral reconstruction (CR) compared with women with FGM who did not undergo CR. Design: Retrospective case-control study Setting: Angers University Hospital, between 2005 and 2017 Methods: Inclusion criteria: pregnant women >18 years who underwent CR after FGM. Only the first subsequent delivery after CR was included. Each woman with CR was matched for age, ethnicity, FGM type, parity, and gestational age at the time of delivery with two women with FGM who did not undergo CR during the same period of time. Main outcome measures: at birth: need for episiotomy and intact perineum Results: 84 women were included ( 28 in the $\mathrm{CR}$ group; 56 in the control group). In the $\mathrm{CR}$ group, patients required significantly fewer episiotomies $(5 / 17[29.4 \%])$ compared to the control group $(28 / 44[63.6 \%], \mathrm{p}=0.02)$, even after excluding operative vaginal deliveries $(2 / 13[15.4 \%]$ vs $21 / 36[58.3], \mathrm{p}<0.01)$. CR reduces the risk of episiotomy $(\mathrm{aOR}=0.15,95 \% \mathrm{CI}[0.04-0.56] ; \mathrm{p}<0.01)$ after adjusting on the infant weight and the need for instrumental delivery. In the CR group, $47 \%$ of the patients had an intact perineum after delivery, compared to $20.4 \%$ in the control group $(\mathrm{p}=0.04)$. CR increases the odds of having an intact perineum at birth by 3.46 times (CI95\%[1.04-11.49]; $\mathrm{p}=0.04$ ). Conclusion: CR after FGM increases the chances of having an intact perineum after delivery by 3.46 times and reduces the risk of episiotomy by 0.15 times compared to women with FGM who did not underwent CR.
\end{abstract}

\section{Hosted file}

BJOG_FGM_manuscript.doc available at https://authorea.com/users/324908/articles/452985effects-of-clitoral-reconstruction-for-female-genital-mutilation-on-perinatal-outcomesa-retrospective-case-control-study

\section{Hosted file}

FGM_table1.docx available at https://authorea.com/users/324908/articles/452985-effectsof-clitoral-reconstruction-for-female-genital-mutilation-on-perinatal-outcomes-aretrospective-case-control-study

\section{Hosted file}

FGM_table2.docx available at https://authorea.com/users/324908/articles/452985-effectsof-clitoral-reconstruction-for-female-genital-mutilation-on-perinatal-outcomes-aretrospective-case-control-study 


\section{Hosted file}

FGM_table3.docx available at https://authorea.com/users/324908/articles/452985-effectsof-clitoral-reconstruction-for-female-genital-mutilation-on-perinatal-outcomes-aretrospective-case-control-study 